\title{
A daily life that has changed forever
}

Bo-Hyoung Jin

Editor-in-Chief, The Journal of Korean Academy of Oral Health

The first case of COVID-19 in Korea was reported on January 19, 20201) and since then, our lives have changed significantly. However, during the last six months, we have learnt to accept these changes.

The guidelines for preventing the spread of COVID-19 by the Korea Centers for Disease Control and Prevention, highlighted the need for social distancing. A report explained the importance of social distancing by using the following example: if an infected person does not practice social distancing, 406 people will get infected within a span of 30 days; however, by reducing one's activity by $50 \%$ and $75 \%$, the number of infected people would reduce to 15 and 2.5 , respectively ${ }^{2}$.

Many experts have predicted that our lives will never return to the way they were, before COVID-19. Thus, it is time that we give due consideration to the measures required for the effective management of oral health.

Oral health professionals are at a high risk of infection, since oral care characteristically requires the treatment to be performed in proximity of within 18 inches of a patient, and significantly exposes a practitioner to a patient's respiratory droplets. This necessitates a more stringent compliance with infection control guidelines, than in the past. This is probably a positive change brought about by COVID-19.

However, there are some concerns regarding the delivery of oral care services. Currently, there is an increased tendency to postpone regular dental check-ups or treatments. It is highly plausible that this could worsen the oral health of the medico-dentally vulnerable population due to lack of timely treatment or proper preventive care.

Therefore, in our field, it is necessary to educate the general public regarding the importance of oral care and provide them with easily accessible and accurate information. Considering that public or group education, as in the past, will no longer be possible for the time being; and in the near future, it may be best to provide information using smart devices and through teledentistry. These will enable effective patient counseling that eventually will become the main focus of patient care. I think we should prepare for the post COVID-19 life through efforts such as reorganizing existing information and establishing new systems to adapt to the upcoming challenges.

June 2020

\footnotetext{
1) Wang C, Horby PW, Hayden FG, Gao GF. A novel coronavirus outbreak of global health concern. Lancet 2020:395:470-473.

2) Singer Laboratory. COVID-19, Coronavirus Calculations \& infographic [Internet]. [cited 2020 Jun 04]. Available from: https://robertsigner. wordpress.com/coronavirus/.
} 


\section{더 이상 돌아갈 수 없는 일상 속에서}

진보형

대한구강보건학회지 편집이사

한국에서 COVID 19 첫 감염자는 2020년 1월 19일에 보고되었다1). 이후 우리의 일상 생활이 변화하기 시작한 지 어느덧 반 년이 되어 가고 있다. 그 6개월의 시간 동안 우리 생활은 정말 많은 변화가 있었고, 우리는 점점 그런 변화된 모습을 자연스럽게 받아들이고 있다.

질병관리본부가 내놓은 코로나 확산 예방을 위한 지침에서 강조하고 있는 것 중의 하나는 사회적 거리두기이다. 사회적 거리두기에 관한 한 자료에 따르면, 감염된 1인이 사회적 거리두기 없이 일상적으로 생활하면 30일 후에 406명을 감염시키고, $50 \%$ 정도 활동량을 줄이면 15 명, $75 \%$ 정도 활동량을 줄이면 2.5 명을 감염시킨다고 하였는데 ${ }^{2}$, 이는 사회적 거리두기의 중요성을 설명하는 한 예이다.

많은 전문가들은 우리가 COVID-19 이전의 생활로 돌아가지 못할 것이라는 예측을 내놓기도 했다. 그럼 이런 시간 속에서 우리는 무엇을 해 야 하며 구강건강관리를 위해서는 어떤 노력을 해야 할지 많은 고민을 해야 한다.

구강진료는 진료 과정의 특수성 때문에 환자의 비말을 통한 감염의 위험성이 너무 높고, 진료 과정도 일반적인 친밀한 관계의 거리인 18 인치 안에서 모든 것이 이루어진다. 이런 환경의 영향으로 진료 현장에서는 과거보다 더 감염관리 지침을 준수하며 실천해 나가고 있는 것으로 판단되 며 이는 COVID-19에 의한 긍정적 변화라고 생각된다.

그러나, 개인구강관리 측면에서는 몇 가지 우려되는 부분이 없지 않다. 과거에 비해 검진이나 진료를 미루는 경향이 높아지면서 제때 치료 시 기를 놓치거나 적절한 예방관리가 이루어지지 않을 확률이 높고, 특히 의료 취약 계층의 구강상태는 더욱 악화될 가능성도 있다.

그러므로 우리 분야에서는 적극적으로 구강관리의 중요성을 교육하고, 직접 국민들이 접할 수 있는 정확한 정보를 꾸준히 제공해 주어야 할 것으로 생각된다. 과거와 같은 집합 교육은 당분간은 더 이상 이루어질 수 없을 것으로 생각되며, 앞으로는 스마트 기기 등을 이용한 정보의 제공 이나 원격 진료 및 상담 등이 대세를 이룰 것으로 판단된다. 우리도 이와 같은 변화에 대비하여 관련 정보를 정비하고 시스템을 구축하는 등의 노 력을 통해 새로운 생활 패턴에 적응할 수 있는 준비를 해야 하지 않을까 생각한다.

2020. 6 .

\footnotetext{
1) Wang C, Horby PW, Hayden FG, Gao GF. A novel coronavirus outbreak of global health concern. Lancet 2020:395:470-473.

2) Singer Laboratory. COVID-19, Coronavirus Calculations \& infographic [Internet]. [cited 2020 Jun 04]. Available from: https://robertsigner. wordpress.com/coronavirus/.
} 